$2-1995$

\title{
Bodies, Texts, and the Social Order: A Reply to Bielefeldt
}

Carolyn Marvin

University of Pennsylvania, cmarvin@asc.upenn.edu

Follow this and additional works at: https://repository.upenn.edu/asc_papers

Part of the Communication Commons

\section{Recommended Citation}

Marvin, C. (1995). Bodies, Texts, and the Social Order: A Reply to Bielefeldt. Quarterly Journal of Speech, 81 103-107. https://doi.org/ $10.1080 / 00335639509384100$ 


\section{Bodies, Texts, and the Social Order: A Reply to Bielefeldt}

\section{Disciplines}

Communication | Social and Behavioral Sciences 


\title{
BODIES, TEXTS, AND THE SOCIAL ORDER: A REPLY TO BIELEFELDT
}

\author{
Carolyn Marvin
}

I'm not sure why Klaus Bielefeldt thinks I trivialize horrible crimes, either those of Nazis or Charles Manson. My characterization of the Manson family murders as a literacy crime may be ironic in tone, but not in logic. American culture constantly circulates messages about the association between illiteracy and violent crime. One of the implicit tasks of popular press descriptions of violent criminals is, in fact, to suggest why such persons commit such awful disruptions of the social order.

If he were to assemble exemplary stories of this kind, I think Klaus Bielefeldt would find that of the many possibly relevant facts about persons accused of particularly violent acts, failures of literacy by community standards - failure to complete schooling at an acceptable level, for example-are among those most likely to be mentioned in order to telegraph the ways in which killers are presumed to differ from the rest of us. Charles Manson fits the pattern. David Koresh is a recent example. Accounts of Koresh constantly noted that he was a high-school dropout. That illiteracy leads to violence is a story told over and over to keep life ordered and in place. Generally speaking, this order assigns texts to high places and bodies to low ones. I assume Klaus Bielefeldt subscribes to it. His conclusion sounds an alarm about a world in which a system of literate control might be replaced by a system of illiterate, or bodily, control. The fact is there is only a system of bodily control, but we go to extraordinary lengths to conceal it behind the literate one.

Like Klaus Bielefeldt, I have little patience with vilifying people because they are male, female, black, white or any other set of attributes. This is not a piece about the evil nature of white male physicians descended from European stock, though some white male physicians of European stock play a role in it. It is a story about the logic of a social system in which those who are skilled at producing and using texts are also more entitled to preserve their bodies and shield them from physical effort and danger. The body, by contrast, is the emblem of those without textual credentials, whose bodies are available to be used up by society and whose powers of social participation derive from whatever value their bodies have for cultural muscle-work, the most dramatic expression of which is war. ${ }^{1}$ Among other things, the power of the textual class is the power to dispose of the bodies and lives of the non-textual class.

It is not a controversial fact that in the nineteenth century many of the persons best situated to acquire and exercise literate power in Europe and the United States were white and male. At the same time, most white males descended from European stock were subject to literate control rather than practitioners of it. And this is still true. In any case, to analyze the historical strategies physicians used to elevate their social status by defining themselves as textually credentialed in contrast to less respectable groups is no more remarkable than, say, tracing efforts by the academy them unsuited for literate work. This is not to say that literacy is an absolute signifier of cultural power. Many elements must be arranged to produce the complex social calculus of status. But in general, more textual credentials have greater privilege than fewer, literacy has privilege over non-literacy, and literacy exhibits deep hostility to the body within this framework. 
Although the surgeon's piece of this story is relatively modern, the story of literate power is not a postmodern one at all. It goes back as far as the history of texts. At its core is the social fiction that writing is disembodied. Though writing can never get rid of the body, misrepresentation and denial enforce the socially constructed boundaries between them. This article examines a representative episode in this process: a moment in the history of medical professionalization when surgeons transformed themselves from artisans of embattled social respectability to textually credentialed professionals with far greater social authority and power than before. Surgeons did not cease to cut bodies or to be associated with the tabooed bodily activities of violence, blood, and death, but they added the power and prestige of a concealing textuality. They became, in short, physicians.

Surgeons are not the only group to make the social transition to literacy. Textualization is a feature of professionalization across occupations. But surgeons are an interesting group to examine because of the lengths to which they must go to textualize their connection to the body. How do you tell a nineteenth-century surgeon from a killer? Surgeons of that era invented strategies to do this, including literate procedures that identified them as members of a textual class entitled to deference, obedience, and even sacrifice of life on the part of those unable to defend themselves.

Part of the larger story is that those who are unable to conceal the connection between bodies and texts, or choose not to, become social monsters or wizards. They transgress a deeply felt divide, a magical border between purity and danger, to use Mary Douglas's categories. What is unnerving about Charles Manson's writing in blood and about books bound in skin - the victims are dead after all; what possible difference can it make what happens to their blood or their skins? - is that they place the indissoluble connection between the body and the text that society tries so hard to deny, squarely, if mostly symbolically, before us. It is we who make monsters or wizards of physicians who take the skins of dead people and use them to cover fine books, or of killers who refuse merely to draw blood, as regular killers do, but write with it as well.

I doubt if it is a new idea to Klaus Bielefeldt that physicians have enormous social authority over bodies. I hope it is not a new idea that the exercise of that control has not always been for the purest motives. If he imagines I excuse other textual groups, including university professors, from accountability for exercising textual power, he is mistaken. "Should I conclude that Carolyn Marvin is at least as literate and, by extension, as oppressive as I am?" he asks. He certainly should. Klaus Bielefeldt calls me to account in the system of literate control. I plead guilty. Some people use guns to maintain their power; others use machetes; many of us use texts. The most powerful texts are directly backed by physical violence. We are diverted, as we are meant to be, by stories of heroic exceptions - writing that exerts influence in spite of guns. But the goal of such writing, more often than not, is to get the guns to join it.

The textual classes are accustomed to deplore bodily force in order to take comfort in their own high-minded (ponder the opposite term) scruples. The rationalization that the textual classes inhabit a world of disembodied ideas in which they are able to refrain from taking part in collisions between bodies permits them not to notice that others do the dirty work of society on their behalf. I mean both work that soils the body and is classified as socially lowly for that reason, and the exercise of bodily force that keeps life safe for the textual classes, but which they often regard as morally dirty. Academicians are as prone as any members of the textual class to deceive themselves about what is required for them 
to maintain their textual position and influence. The business of elucidating the connections between literate practice and the control of bodies is the job of analysis.

If there is a hidden message here, it is not about physicians - I tried to be as clear as possible there-but about all who guard textual institutions, punishments, and rewards. Literacy has long been considered a great liberator, and it is. But like everything else that human beings create, it has other effects as well. Medicine is no different. We have recently learned of troubling practices since World War II by American scientists and physicians engaged in government studies of the effects variously of psychotropic drugs, radiation, and syphilis on the bodies of citizens unable or unasked to give meaningful consent. Physicians and scientists may do "studies" for the love of humankind, but the term refers to the process of producing and disseminating texts, especially journal articles and resumes that literally conceal the bodies that suffered to produce them. In my view, the suffering of the subjects in these studies (which I do not suggest Klaus Bielefeldt would defend for a minute) re-models that of indigent patients in nineteenth-century hospitals, and inmates subjected to experiments in concentration camps. I am sorry if Klaus Bielefeldt finds the latter comparison offensive, but I am not the only one making it. In records released by the Department of Energy, physicians involved in the radiation experiments of the 1950 s made it themselves.

On the subject of Nazis, the fact is that it is hard to uncover reliable evidence that the Nazis bound books in human skin. There seems to be good evidence that they used human skin to make other sorts of artifacts, though I have not pursued most of this evidence to its limits. This does not mean the Nazis did not bind books in human skin. It simply means there is no convincing evidence available, as there is about gas chambers, forced labor camps, dare I mention medical experiments, and other forms of mistreatment. Such evidence may emerge from recently opened archives in eastern Europe. But this piece was not about the atrocities of the Nazis, whom I originally hoped, to leave out altogether. My subject was not them, but the exotic bookbinding practices of some nineteenth-century physicians. Audiences to whom I presented this research in progress, however, constantly provided associations with the Nazis. A large number of people claim to know that Nazis bound books in human skin. It is a compelling fact that tales of Nazi atrocities attach themselves so assiduously to stories about physicians binding books in human skin. In trying to understand it, I speculate that these may be disguised folk memories of a time when physicians had far more tenuous claims to respectability, were far less regulated (the textual classes are also disciplined) and far less textually credentialed.

Klaus Bielefeldt accuses me of believing in original sin. Again I plead guilty, since I have never found any human enterprise or theory that is immaculate in its conception, a peculiar nation about how the word became flesh in the absence of carnal knowledge, which is presumed to be contaminated. Perhaps fertile ideas are inevitably sinful ideas. I do not advocate illiteracy, naive or otherwise, but the belief that literacy is innocent is very naive. At best, literacy is a complex social process. It serves many purposes, including social control. Among students of literacy, this is not an unusual observation. What I added was not the notion that literacy is related to power, but that its power is constructed around the body, that this fact is constantly denied, and that both the fact and the denial play themselves out in complicated ways in the social order. Among them is that literacy is a system for allocating bodies, and for allocating resources to socially favored bodies.

The purpose of this article was not to defend literacy. Every member of the textual class knows this defense by heart. Nor, as an original sinner, do I advocate dismantling the edifices of literacy, 
though I hardly think they are above reform. I believe it is important to examine the workings of a social system that makes adversaries of bodies and texts, so that those of us who exercise privilege in it can answer in a more responsible fashion. But this is not a public policy piece, either. It is an effort to understand a fundamental and sturdy aspect of the social order, to explore how things come to make sense in the way they do.

One final point. Klaus Bielefeldt claims my conclusion that some nineteenth century physicians viewed their indigent patients with contempt is based on questionable assertions about the nature of materials used in bookbinding. He asserts a connection I did not make. I was quite clear about particular cases where claims about the composition of bindings are in doubt. The pattern of physician ownership of books bound in human skin emerged from the most probable cases, not the least probable. From these most probable cases, I selected the cases of Leidy and Stockton-Hough, about which I am especially confident, to examine further. These particular bindings have not been subjected to chemical analysis, the only sure test of their composition. But the convergence of several kinds of evidence, including testimony by the principals or their families, accounts by contemporaries, and the existence of other artifacts or documents offering independent confirmation, establishes a convincing case that in these instances we are dealing with books bound in human skin. Besides, to doubt it would be to call respectable physicians liars, and Klaus Bielefeldt thinks I have been mean enough to them already.

My characterization of some physicians' attitudes toward the patients who served them as anatomical subjects does not derive from the fact that they bound books in the skins of their patients. As far as I can tell, few did. It derives from testimony during legislative debates about the acquisition of cadavers for medical study and teaching. In this testimony some of the most prominent physicians of the period display a cavalier and arrogant attitude about those on whom they exercised their craft without controls or accountability. I invite Klaus Bielefeldt to read it. There is also much evidence that physicians in pursuit of cadavers regularly deceived families and patients to acquire- them. These indignities, real and perceived, produced popular riots and eventually, regulation, since public opinion came to see as intolerable the unregulated use of poor people as anatomical subjects for dissection in teaching hospitals. I did not base my conclusions about physician attitudes on anthropodermic bookbinding, as Klaus Bielefeldt suggests. I located anthropodermic bookbinding with reference to this constellation of attitudes, which provided the atmosphere in which some physicians found it reasonable to use human flesh to bind books. I also suggest that binding the skin of patients was probably a tribute to them by some of the physicians who did it, whatever Klaus Bielefeldt's view or mine may be. In the end, of course, this is an interpretive exercise arranging pieces of historical evidence much as a physician makes a clinical diagnosis, a point Klaus Bielefeldt recognizes. Each reader will have to judge how satisfactory it is.

\section{NOTES}

Carolyn Marvin is Associate Professor of Communication, The Annenberg School for Communication, University of Pennsylvania.

${ }^{1}$ For a more extended discussion, see Carolyn Marvin, "Theorizing the Flagbody: Symbolic Dimensions of the Flag Desecration Debate, or, Why the Bill of Rights Does Not Fly in the Ballpark," Critical Studies in Mass Communication 8 (1991): 119-138. 